\title{
Prognostic factors in prostate cancer
}

\section{A Buhmeida*1, S Pyrhönen ${ }^{1}, \mathrm{M} \mathrm{Laato}^{3}$ and Y Collan ${ }^{2}$}

Address: ${ }^{1}$ Departments of Oncology and Radiotherapy, Turku University Hospital, Turku, Finland, ${ }^{2}$ Departments of Pathology, Turku University Hospital, Turku, Finland and ${ }^{3}$ Departments of Surgery, Turku University Hospital, Turku, Finland

Email: A Buhmeida* - abuhme@utu.fi; S Pyrhönen - seppo.pyrhonen@tyks.fi; M Laato - matti.laato@tyks.fi; Y Collan - yrjo.collan@utu.fi

* Corresponding author

Published: 03 April 2006

Diagnostic Pathology 2006, I:4 doi:10.1 186/1746-1596-1-4

This article is available from: http://www.diagnosticpathology.org/content/l///4

(C) 2006 Buhmeida et al; licensee BioMed Central Ltd.

This is an Open Access article distributed under the terms of the Creative Commons Attribution License (http://creativecommons.org/licenses/by/2.0), which permits unrestricted use, distribution, and reproduction in any medium, provided the original work is properly cited.

\begin{abstract}
Prognostic factors in organ confined prostate cancer will reflect survival after surgical radical prostatectomy. Gleason score, tumour volume, surgical margins and Ki-67 index have the most significant prognosticators. Also the origins from the transitional zone, p53 status in cancer tissue, stage, and aneuploidy have shown prognostic significance. Progression-associated features include Gleason score, stage, and capsular invasion, but PSA is also highly significant. Progression can also be predicted with biological markers (E-cadherin, microvessel density, and aneuploidy) with high level of significance. Other prognostic features of clinical or PSA-associated progression include age, IGF-I, p27, and Ki-67. In patients who were treated with radiotherapy the survival was potentially predictable with age, race and $\mathrm{p} 53$, but available research on other markers is limited. The most significant published survival-associated prognosticators of prostate cancer with extension outside prostate are microvessel density and total blood PSA. However, survival can potentially be predicted by other markers like androgen receptor, and Ki-67-positive cell fraction. In advanced prostate cancer nuclear morphometry and Gleason score are the most highly significant progression-associated prognosticators. In conclusion, Gleason score, capsular invasion, blood PSA, stage, and aneuploidy are the best markers of progression in organ confined disease. Other biological markers are less important. In advanced disease Gleason score and nuclear morphometry can be used as predictors of progression. Compound prognostic factors based on combinations of single prognosticators, or on gene expression profiles (tested by DNA arrays) are promising, but clinically relevant data is still lacking.
\end{abstract}

\section{Introduction}

Prostate cancer is the most common malignancy in men and the second leading cause of cancer death in the Western world [1-3]. Today, more patients with prostate cancer are being diagnosed in early stages of the disease than used to be the case 10 years ago. The increasing incidence may be due to increased PSA-measurements and other diagnostic efforts. However, this review does not handle the associated differential diagnosis. Also, the biological heterogeneity that characterizes this disease causes deci- sion issues unique to prostate cancer. Low-grade cancer diagnosed late in life may have no impact on the quality or length of life. A younger man with a high-grade lesion may have advanced disease and die within a couple of years. Biological distinction of such patients should have a high priority in continuing research.

Although prostate cancer is very prevalent among men, relatively little is known about the molecular mechanisms involved in the development and progression of the dis- 
ease [4-7]. The lack of knowledge on the biology of prostate cancer has resulted in numerous controversies on the clinical management of the early stages and on the utility of population screening [8].

One of the aims of molecular genetics is to reveal the genetic alterations and genes that are involved in disease processes. Molecular pathogenesis of the prostate cancer is poorly understood. Over the past 10 years, chromosomal aberrations in prostate cancer have been studied with several techniques, such as loss of heterozygosity (LOH), fluoresence in situ hybridization (FISH), comparative genomic hybridization (CGH), suppression substractive hybridization ( $\mathrm{SSH}$ ) and cDNA array hybridization. FISH has been used to identify the target genes for some of these chromosomal alterations [9]. These chromosomal alterations are most likely to harbour the genes critical for the progression of prostate cancer [10].

After the diagnosis is established, the physician wants to determine whether the lesion is confined to the prostate gland (and is hence potentially curable), or whether cancer has spread beyond the prostate and is incurable. At the present time, the successful radical treatment of prostate cancer is limited to the patients with organ-confined disease.

On the other hand, there are also latent prostate cancers. Most patients with latent prostate cancer die with, rather than of, prostate cancer. Against this background we should concentrate in finding objective criteria for distinguishing between clinically significant and clinically insignificant cancers, usually falling into the category of latent prostate cancer [11]. In other words, it is becoming increasingly important to find factors, which could predict which patients have tumours with aggressive invasive potential to spread outside the prostate [12]. Various types of clinical and pathological information may contribute in building decision making systems or tools for this purpose. Clinicians treating prostate cancer patients may potentially use these tools.

The management could be in the form of early detection and identification of prognostic factors, which help in forecasting the outcome in an individual case. Perfect forecasting could help in selecting the treatment mode that would be most appropriate for the treatment of an individual patient. So patients with favourable outcome if identified - would not need crippling therapy whereas patients with a high risk of early metastasis or death would be placed in the group of more intensive treatment and surveillance follow up. This is also important after surgical radical prostatectomy, which offers lot of material for analysis and creates a challenge for the pathologists [13]
Unfortunately, general reliable forecasting of the outcome is still not possible, and efforts to identify prostate cancer prognosticators must continue [14]. So, it is important to answer the question: What are the histolgical, cell biological and molecular features which could differentiate between aggressive and non-aggressive types of prostate cancer?

The intention of this review is to shed light on the above questions by reviewing the most widely studied prognostic factors to help the clinicians to create practical prognostic models that can potentially also help in individualization of the treatment. Some of these important prognostic factors are summarized in Table 1.

\section{Clinico-pathological prognostic factors}

Clinical prognostic factors are those that can be assessed through physical examination: blood tests, radiological evaluation, and microscopy of biopsy material. Clinical factors are important because they allow the cancer to be characterized before a definitive treatment decision is made. In this review article, pathological prognostic factors are those that require examination, removal, and evaluation of the entire prostate.

\section{Age of patient}

The role of the age of the patient per se as a significant prognostic factor in prostate cancer is controversial $[15,16]$. 567 patients completing external beam radiotherapy were examined by Herold et al [17]. In addition to other factors, age of the patients greater than 65 years was a significant predictor of distant metastases at 5 years. They concluded that men over the age of 65 years were more likely to experience distant failure after radical radiation therapy than were younger men. Obek et al [18] also suggested that young age per se might be an independent favourable prognostic factor for disease recurrence after surgical radical prostatectomy. Also Freedland et al [19] found that young men had more favourable outcomes after surgical radical prostatectomy (RP) than older men, which made younger men suitable subjects in screening.

\section{Volume}

Although tumour volume is an important factor in predicting prognosis in carcinoma of the prostate, direct and accurate estimation of tumour volume is not practical clinically. This is because the tumour may not always be palpable, and when palpable the volume cannot be evaluated in 3 dimensions [20]. Transrectal ultrasound (TRUS) used as a tool for estimating the tumour volume either directly (Terris et al 1992) [21] or as a guide for core biopsies $[22,23]$ has only limited ability to estimate prostate cancer volume. 176 radical prostatectomy specimens were studied with respect to cancer volume by McNeal et al [24]. They found that the extent of capsular penetration, 
Table I: Prognostic factors associated with prostate cancer after different types of treatment and according to the level of extension. Patients with organ confined disease treated with radical prostatectomy (surgical or radiated), and patients with more extensive disease are presented separately. The database applied was PubMed, the presented papers were published during years $1989-2005$.

\begin{tabular}{|c|c|c|c|c|c|}
\hline \multicolumn{6}{|c|}{ Organ confined disease, radical prostatectomy (surgical) } \\
\hline \multicolumn{3}{|c|}{ Survival-associated prognosticators } & \multicolumn{3}{|c|}{ Progression-associated prognosticators } \\
\hline Prognosticator & p value & Reference & Prognosticator & p value & Reference \\
\hline Tumour volume & $<0.009$ & Salomon et al. & Age & $<0.01$ & Obek et al. \\
\hline Gleason score & $<0.0002$ & Hoznek et al. & Gleason score & $<0.0001$ & Epstein et al. \\
\hline Surgical margin & $<0.009$ & Hoznek et al. & Capsular invasion & $<0.001$ & Wheeler et al. \\
\hline Tranzitional zone & $<0.04$ & Augustin et al. & PSA* & $<0.001$ & Salomon et al \\
\hline p53 & $<0.011$ & Kuczyk et al. & Surgical margin & $<0.075$ & Bloom et al. \\
\hline Stage & $<0.02$ & Kuczyk et al. & E-cadherin & $<0.005$ & Umbas et al. \\
\hline p27 & $<0.01$ & Yang et al. & IGF-I** & $<0.05$ & Yu et al. \\
\hline Aneuploidy & $<0.02$ & Zincke et al. & Stage & $<0.001$ & D'Amico et al. \\
\hline $\mathrm{Ki}-67$ & $<0.001$ & Bettencourt et al. & MVD*** & $<0.007$ & Halvorsin et al. \\
\hline \multirow[t]{5}{*}{ cDNA microarray } & $<0.01$ & Susan et al. & p27 & $<0.008$ & Yang et al. \\
\hline & & & Aneuploidy & $<0.0001$ & Zincke et al. \\
\hline & & & Aneuploidy & $<0.001$ & Ross et al. \\
\hline & & & $\mathrm{Ki}-67$ & $<0.02$ & Bubendorf et al. \\
\hline & & & $\mathrm{MUCl}$ & $<0.003$ & Lapointe et al. \\
\hline \multicolumn{6}{|c|}{ Organ confined disease, radical prostatectomy (radiation) } \\
\hline \multicolumn{3}{|c|}{ Survival-associated prognosticators } & \multicolumn{3}{|c|}{ Progression-associated prognosticators } \\
\hline Prognosticator & p value & Reference & Prognosticator & p value & Reference \\
\hline \multirow[t]{2}{*}{ Age } & $<0.02$ & Austin el al. & & & \\
\hline & & & Age & $<0.01$ & Neulander et al \\
\hline \multirow[t]{2}{*}{ Race } & $<0.02$ & Austin et al. & & & \\
\hline & & & Gleason score & $<0.001$ & Kupelian et al. \\
\hline \multirow[t]{2}{*}{ p53 } & $<0.02$ & Grignon et al. & & & \\
\hline & & & Radiation dose & $<0.001$ & Kupelian et al. \\
\hline \multicolumn{6}{|c|}{ Prostate cancer with extension outside the prostate (advanced disease) } \\
\hline \multicolumn{3}{|c|}{ Survival-associated prognosticators } & \multicolumn{3}{|c|}{ Progression-associated prognosticators } \\
\hline Prognosticator & p value & Reference & Prognosticator & $p$ value & Reference \\
\hline $\mathrm{AR}$ ***** & $<0.01$ & Segawa et al. & Nuclear morphometry & $<0.01$ & Partin et al. \\
\hline$A R$ & $<0.02$ & Miyoshi et al. & Nuclear morphometry & $<0.0003$ & Vesalainen et al. \\
\hline Total-PSA & $<0.001$ & Bjork et al. & Gleason score & $<0.0001$ & Vesalainen et al. \\
\hline MVD & $<0.0001$ & Borre et al. & Gleason score & $<0.007$ & Shurbaji et al. \\
\hline \multirow[t]{3}{*}{ Ki-67 } & $<0.02$ & Aaltomaa et al. & AR & $<0.03$ & Sadi et al. \\
\hline & & & $\mathrm{p} 53$ & $<0.018$ & Bauer et al. \\
\hline & & & bcl-2 & $<0.004$ & Bauer et al. \\
\hline
\end{tabular}

* Prostate Specific Antigen, ** Insulin-like Growth Factor, *** Microvessel density, **** Androgen Receptor

cancer volume, and positive nodes were strongly intercorrelated. Twelve cubic centimetres was the critical volume. Higher volumes were usually associated with extensive capsular penetration, positive surgical margins, and/ or positive nodes.

To determine which of these three variables provided independent prediction of prognosis Epstein et al [25] evaluated 185 men following surgical radical prostatectomy for stage $\mathrm{T} 2$ disease. The patients were re-evaluated at 5 years after prostatectomy and grouped into 2 groups: those free of disease, and those who experienced progression. The study accepted only cases with negative pelvic lymph nodes and with negative seminal vesicles at the time of the diagnosis. At five years following radical pros- tatectomy, 58 men (31\%) had experienced progression. Gleason grade, surgical margins, and tumour volume each where highly correlated with progression. In stepwise regression analysis, tumour volume did not provide independent prognostic information beyond that provided by Gleason score and the status of surgical margins.

The study by Bostwick et al [26] for evaluating the utility of tumour volume in predicting progression of early prostate cancer revealed that tumour volume was a significant predictor of cancer progression. They found that there was a $10 \%$ probability of capsular invasion in tumours measuring about $0.5 \mathrm{~cm}^{3}, 10 \%$ probability of seminal vesicle invasion in tumours measuring about $4.0 \mathrm{~cm}^{3}$, and $10 \%$ probability of distant metastases in tumours measuring 
about $5.0 \mathrm{~cm}^{3}$. As described by McNeal et al [27] loss of differentiation and potential to give rise to metastases were strongly correlated with tumour volume. In contrast to the previous results, Salomon et al [28] showed that tumour volume does not provide additional information to predict prostate cancer progression after radical prostatectomy. The same was concluded by Kikuchi et al [29]. Simply because tumour volume does not give additional prognostic value to the Gleason score, many centers do not consider it valuable in clinical practice [13]. However, if better prognosticators are not available, the volume is still a valuable guide in prognostication.

\section{Grading}

All existing grading systems successfully identify well-differentiated cancer, which progresses slowly, and poorly differentiated cancer, which progresses rapidly, but they are less successful in subdividing moderately differentiated cancers, which have an intermediate malignant potential [30]. The histological Gleason score of the adenocarcinoma of the prostate is a good and an established prognostic indicator.

Dr Donald F Gleason [31] and members of the Veterans Administration Cooperative Urological Research Group devised the Gleason grading method in the 1960s and 1970 s. This grading system is based entirely on the histological pattern of differentiation and arrangement of carcinoma cells and cell groups in H\&E-stained sections. Five basic patterns (scored 1-5) are used to generate a histological sum score (summed from scores of two most dominant patterns), which can range from 2 to 10 [32]. Gleason grading of the cancer is the most widely used, and accepted histopathological method for providing information about the prognosis of prostate cancer. Univariate and multivariate analyses of prognosis in prostate cancer almost always identify Gleason grade as one of the most significant predictors of patient outcome [33]. A 3-grade grading system is also in use, but no longer recommended [13]. Also, models have been developed which allow for pre-treatment prediction of pathologic stage on the basis of needle biopsy Gleason grade, total serum prostate-specific antigen level, and clinical stage [34]. It is of considerable interest to know how accurate the needle biopsy Gleason score is in relation to Gleason score obtained from the radical prostatectomy samples [35]. Over half of the patients are under- or over-graded by needle biopsy. Clinicians should be aware of this potential inaccuracy when using Gleason grading in decision-making [36]. Koksal et al [37] found that grading error was greatest in well-differentiated tumours and true sum scores between $2-4$. The grading error decreased with increasing Gleason score. The same was concluded by Shen et al [38]. Tumours with combined Gleason scores of 2-4 are not commonly present in needle biopsy material, since palpable tumours are usually of a higher grade [39].

Two important studies $[40,41]$ have demonstrated a good correlation between the prognosis of prostate cancer and combined Gleason scores. Even when a high-grade tumour is organ confined, it is associated with a relatively unfavourable short-term outcome that is not predictable on the basis of either preoperative clinicopathologic data or postoperative pathologic information obtained from the radical prostatectomy specimen [42]. The study by Cheng et al [43] showed that the combined percentage of Gleason patterns 4 and 5 is the best predictor of progression after radical prostatectomy. This is why the percentage of patterns 4 and 5 should today be reported in histopathological evaluation. With Partin coefficient tables it is possible to calculate risks for recurrence [44]

\section{Extracapsular extension}

In rectal examination the incidence of capsular penetration in palpable clinically confined tumours is $20-38 \%$ or $40-66 \%$ (unilateral or bilateral tumours, respectively) [45,46]. The study of 196 tumours by Epstein et al [47] demonstrated that tumours with more extensive capsular penetration had a higher risk of progression than those showing focal capsular penetrations. One-hundred thirty (130) patients with follow up of more than 10 years after radical prostatectomy were histologically restaged by Theiss et al [48]. They found that in contrast to capsular invasion as such, capsular penetration is an indicator of poor prognosis. Capsular penetration was associated with higher progression rate and reduced survival. They recommended that tumours with capsular invasion and those with capsular penetration should be distinguished. Ohori et al [49] found that the probability of progression-free survival at 7 years was $65 \%$ for patients with extracapsular extension and positive margins and a Gleason score of 6 or less, and $40 \%$ for patients with extracapsular extension and positive surgical margins and a Gleason score of 7 or more. To assess the relationship between the level and extent of prostatic capsular invasion by cancer, the clinical and pathological features, and prognosis of early state prostate cancer Wheeler et al [50] used multivariate analysis. They found that the level of capsular invasion was an independent prognostic factor and a strong association between the level of invasion of cancer into or through the prostatic capsule and the volume, grade, pathological stage, and the rate of recurrence after radical prostatectomy. Also they concluded that sub-classification of patients according to the levels of prostatic capsular invasion provides valuable prognostic information.

\section{Seminal vesicle invasion}

In most recent studies, seminal vesicle invasion (SVI) is a poor prognostic parameter $[51,52]$, with biochemical pro- 
gression-free rates ranging from $5-60 \%$. The differences may be related to the definition of the seminal vesicle invasion. Some authors consider an intraprostatic portion of the seminal vesicle as true seminal vesicle, and as such consider its involvement by cancer as seminal vesicle invasion. Others call any seminal vesicle as extracapsular extension [53]. Some studies do not make any distinction between the seminal vesicles and the ejaculatory duct complex.

Seminal vesicle invasion is associated with high PSA failure rates (PSA levels not changed to normal) after radical prostatectomy, and subsequent distant metastases [54]. Debras et al, [55] evaluated the prognostic significance of SVI in radical prostatectomy specimens according to proximal or distal site of invasion. They concluded that the prognostic significance of SVI is not constant and depends on the site of invasion, in which patients with invasion extending to the free part of the seminal vesicles have poorer prognosis than those patients with invasion only limited to the proximal part of the seminal vesicles.

115 cases of established capsular penetration, 16 of periseminal vesicle invasion, and 45 of seminal vesicle invasion in-patients without lymph node metastases were evaluated by Epstein et al (1993c). They concluded that patients with SVI had a significantly worse prognosis than those with capsular penetration, and peri-seminal vesicle invasion was associated with an intermediate risk of progression. The results of Freedland et al [56] revealed that patients with SVI had significantly higher PSA values, higher clinical stage, higher grade tumours, and were more likely to have concomitant extracapsular extension or a positive surgical margin. The study also identified a subset of men with low-grade disease, negative surgical margins, and older age, who - despite SVI - had an extremely favourable clinical course. The study concluded that SVI does not consistently suggest an unfavourable prognosis.

\section{Zone of origin}

The development of zonal anatomy of the prostate reported by McNeal $[57,58]$ allows the assignment of the zone of origin to individual prostate cancer foci. Cancer foci detected incidentally in tissue removed by transurethral resection of prostate (TURP) (stage A) are predominantly of transitional zone (TZ), while clinically palpable (stage B) cancers are predominantly of peripheral zone (PZ) origin [59]. McNeal identified $68 \%$ of small prostate cancers as originating from the peripheral zone (PZ), 24\% from the transitional zone (TZ), and $8 \%$ from the central zone (CZ).

To determine the characteristics of transition zone and peripheral zone prostate cancer, Greene et al [60] exam- ined a series of 42 stage A and 54-stage B radical prostatectomy specimens. They paid particular attention to the number of separate foci of cancer, zone of origin, volume and grade of foci, presence of severe intraductal dysplasia, extra-capsular extension, and seminal vesicle invasion associated with cancer in each zone. They found that there were fundamental differences between transitional zone (TZ) and peripheral zone (PZ) cancers. Cancer that arises in the transitional zone is associated with more favourable pathological features and may have less malignant potential than tumours that arise in the peripheral zone. The results of Augustin et al [61] showed that patients with tumours including $70 \%$ or more of the cancer volume in the TZ had a significantly higher rate of biochemical cure than those with $30 \%$ or less. Jack et al [62] revealed that transitional zone tumours were favourable with higher rate of organ confined and lower grade tumours. They concluded that if transitional zone tumours prove to be biologically distinct, improved strategies to identify these lesions preoperatively might result in more conservative treatment recommendations.

\section{Heterogeneity and multicentricity}

As early as 1935, Moore had recognized that prostatic carcinomas are often multifocal [63]. Prostatic carcinoma is characteristically multifocal with as many as 5 or 6 tumours occurring in a single prostate [64]. A great challenge for diagnostic pathologists was the characteristic heterogeneous appearance of prostatic carcinoma. The availability of radical prostatectomy specimens has provided the opportunity to examine the interrelationships of histological heterogeneity and multicentricity in individual specimens [65]. The influence of grade heterogeneity and tumour multifocality on the ability to predict the prognosis of patients with prostate cancer is profound. The multifocal and heterogeneous nature of prostate makes it difficult to obtain representative biopsy samples from the tumours [66]. Hammerer and associates [67] considered the number of biopsies positive for cancer as quantitative measure of tumour multicentricity. The data of Djavan et al [68] suggested that multifocal prostate cancer is associated with higher grade, stage, and recurrence rate than unifocal prostate cancer.

\section{Morphometric features}

In 1982 Diamond and associates introduced nuclear morphometry to aid in prediction of prognosis among patients with prostate cancer $[69,70]$. He and his colleagues observed that nuclear roundness was very useful in separating long survivors among stage B patients from those who develop metastasis. They observed no overlap in nuclear roundness between the two groups. Since then, many histological studies [71-75] have used nuclear morphometry to predict prognosis in patients with prostate cancer. Eichenberger and associates [73] calculated 12 
shape descriptors including nuclear roundness, ellipticity factors, and concavity factors. They used discriminate analysis to select the major morphometric parameters which best distinguished patients with good or poor prognosis. Elliptical shape measurement was found to be the best in this respect.

To evaluate critically the usefulness of nuclear morphometry for prediction of prognosis, Partin et al [75] developed a morphometric evaluation system called Hopkin's Morphometry System, and produced and compared 15 different shape descriptors in stage A2 prostate cancer. These were analysed by 17 different statistical tests. The best separation was provided by the lower quartile analysis of the ellipticity shape descriptor $(p<0.01)$. These studied revealed that elliptical shape of the nuclei is very important as prognostic factor.

Variance of nuclear roundness combined with clinical stage, Gleason score, and age produced a prognostic score capable of stratifying patients with clinically localized cancers into three groups with different disease free survival [76].

Aragona et al [77] concentrated on the role of size features. They found that accurate prediction for well-differentiated adenocarcinoma was attained using mean nuclear area $\left(>28 \mu \mathrm{m}^{2}\right.$, mean nuclear diameter $(>5 \mu \mathrm{m})$ and the presence of more than $5 \%$ of cells with a nuclear diameter greater than $(6.16 \mu \mathrm{m})$.

A series of 325 patients with prostatic adenocarcinoma were followed-up for over 13 years by Vesalainen et al [78]. The patients were subjected to histomorphometric analysis for the following prognostic factors: the Gleason score and 10 nuclear morphometric factors (mean nuclear area, nuclear perimeter, and shortest and longest nuclear factors, form factors and their SDs). They found that in T1$2 \mathrm{MO}$ tumours, all of these parameters were significant prognostic factors. The results of study by Martinez-Jabaloyas et al [79] revealed that mean nuclear area and other factors proved to have prognostic value in the univariate analysis and concluded [80] that nuclear morphometry in the primitive tumour provides independent prognostic information in survival analysis for patients with metastatic prostate cancer. The combined evaluation of high nuclear morphology, ploidy and cell survival parameters such as Bcl-2 expression might better identify patients with poor prognosis among early stage prostate carcinomas diagnosed by FNA biopsies [81].

Beside to the prognostic and predictive power of morphometry, Buhmeida et al [82] revealed that the nuclear size features are useful in distinguishing between different atypia groups of prostate gland in fine needle aspiration biopsies, particularly if the sample-associated means of the size features (area, diameter, perimeter, short and long axes) are used for the interpretation of data. The study suggested that if the upper range limit of sample-associated mean areas of nuclei is below $27 \mu \mathrm{m}^{2}$, it is most probable that we are dealing with benign cells. If the upper range limit is above $39 \mu \mathrm{m}^{2}$, it is possible that there are malignant cells in the sample. However, values above $52 \mu \mathrm{m}^{2}$ represent malignant samples with certainty. Further studies will be necessary for associating nuclear size features with Gleason grades.

\section{Biological prognostic factors \\ E-cadherin}

Normally functioning cell-cell adhesion plays an important role in the maintenance of tissue architecture and cohesion. E-cadherin is an important adhesion molecule in epithelial cells. E-cadherin expression has been proposed for predicting prognosis in prostate adenocarcinoma. A study of E-cadherin levels by immunohistochemistry in nonmalignant and malignant specimens of human prostatic tissue revealed that almost $50 \%$ of tumours examined had reduced levels of this protein, and in some tumours E-cadherin was absent altogether when compared to non-malignant prostate, which uniformly stained strongly positive [83]. To determine the potential prognostic significance of the findings, prostate cancer specimens from 89 patients were evaluated immunohistochemically using specific antibodies raised against E-cadherin [84]. The results were related to histological grade, tumour stage, presence of metastasis, and survival. Patients showing low immunohistochemical expression of E-cadherin have on average shorter survival than patients with high immunohistochemical expression.

Because mutational inactivation of alpha-catenin can be the cause of the impaired E-cadherin function, Umbas et al [85] studied the relationship between E-cadherin and alpha-catenin expression. The results suggest that loss of alpha-catenin expression could be one of the mechanisms responsible for the loss of E-cadherin mediated cell-cell adhesion in human prostate cancer and might in some cases provide prognostic information. The same was concluded by Aaltomaa et al [86] who studied the expression of alpha-catenin in locally advanced prostate cancer. They found that alpha-catenin had prognostic significance in the early phases of cancer progression. Low alpha-catenin expression was related to worse prognosis than high alpha-catenin expression. De-Marzo et al [87] correlated the down-regulation of E-cadherin and pathologic stage at radical prostatectomy. In univariate analysis they found that reduced levels of E-cadherin correlated with advanced Gleason score $(p=0.003)$ and advanced pathologic stage $(p=0.008)$. In multivariate analysis, E-cadherin, preoperative PSA, and Gleason score all contributed independ- 
ently to the prediction of high stage disease ( $p<0.001)$. They concluded that a prospective study on E-cadherin is warranted. The study should evaluate E-cadherin as a potential biomarker of disease progression in patients with clinically organ-confined prostate cancer who undergo radical prostatectomy. Moderate or strong expression of a transcriptional repressor EZH2 (enhancer of zestor homolog2) coupled with at most moderate expression of E-cadherin was the biomarker combination that was most strongly associated with recurrence of prostate cancer [88]. In the clinical situation low E-cadherin immunostaining suggested clinical recurrence. But to what extent and at what level of accuracy the status of an individual patient can be predicted should be evaluated in further studies.

\section{Insulin-like growth factor (IGF)}

The insulin-like growth factor (IGF) system is composed of two ligands (IGF-I and IGF-II), two receptors (IGFR-I and IGFR-II) and six binding proteins (IGFBP 1 to 6 ). Mita et al [89] found that IGF-II and IGFBP2 play a role in prostate cancer progression and their increased expression is a prognostic indicator in hormone- treated prostate cancer patients. The results of the study by Figueroa and co-workers [90] indicate that the higher expression of IGFBPs in human prostate cancer correlates with the Gleason score, and the expression of certain IGFBPs may be used as markers of aggressive clinical behaviour. After studying changes in IGFBP2 and IGFBP3 levels in serial postoperative serum samples from prostate cancer in patients with and without relapse, Yu et al [91] suggested that IGFBP2 may play a role in the progression of prostate cancer, but that serum levels of IGF-I and IGFBP3 have no predictive value in the progression of prostate cancer. However, the high preoperative circulating plasma insulin-like growth factor (IGF-I) levels have been correlated with increased risk of prostate cancer [92-94].

\section{Androgen receptors (AR)}

The androgen receptor (AR) is a nuclear transcription factor that binds male sex steroids and mediates the biological effects of these hormones in the target cells by activating transcription of androgen-dependent genes. The AR gene is localized on chromosome $\mathrm{X}$ and it contains a series of CAG trinucleotide repeats. The length of CAG repeats varies among individuals and this polymorphism is believed to be related to the transcriptional activity of AR. Fewer CAG repeats are associated with increased risk of developing tumour as well as more aggressive forms of prostate cancer and breast cancer of women [95].

Withdrawal of androgens or peripheral blockade of androgen action is a critical therapeutic option in the treatment of advanced prostate cancer. However, after initial regression, many prostate cancers become hormone refractory and progress further with eventually fatal outcome. A large number of different molecular mechanisms may be responsible for the development of hormonerefractory recurrent tumours. Many of these involve the AR gene and its complex downstream signalling pathways [96]. Mutations in the coding region of the AR gene have been found in both untreated and hormone-refractory prostate cancer [97]. Segawa et al [98] demonstrated that AR expression was significantly lower in adenocarcinoma than is non-tumour prostate tissues. They also found that there is significant correlation between progression free survival and AR expression or proliferative activity. High AR expression predicted high proliferative activity and short progression free survival. Similarly, the results of Miyoshi et al [99] showed the AR expression level in hormone-refractory prostate cancer specimens was significantly lower than that in previously untreated prostate cancer or benign prostatic hyperplasia (BPH) specimens. The results suggested that a higher AR expression level result in poor recurrence-free survival and poor overall survival in hormone-refractory prostate cancer patients. The greater AR heterogeneity in poor responders may reflect a greater genetic instability in tumours that have progressed toward androgen independence i.e., many of the growth factors may exhibit their effects via crosstalk with AR [100]. AR heterogeneity may consequently be used as a predictor of treatment response and as a sign of progression [101]. Magi-Galluzzi et al [102] suggested that the heterogeneity in the expression of the androgen receptors increases with progression of invasive prostate cancer and might in part account for variable response to endocrine therapy.

\section{Prostate specific antigen (PSA)}

Prostate cancer causes the release of a number of substances into the blood stream. Of these, prostate specific acid phosphatase (PSAP) and prostate specific antigen (PSA) are clinically most important, and can be used for screening for prostate cancer, and for monitoring the response to treatment. To a degree PSA also provides diagnostic information [103]. Of the molecular forms of PSA, especially the free PSA seems to be useful for the detection of prostate cancer in men whose total PSA concentrations fall in the 4-10 microg/l range [104]. The values of total PSA (tPSA), free PSA (fPSA) and PSA complexed to alpha1-antitchymotrypsin (PSA-ACT) are all independent prognostic factors of prostate cancer survival [105]. Serum PSA levels are strong prognostic determinants of outcome following radiotherapy for prostate cancer and appear to add prognostic information independent of tumour stage and grade [106]. After radical prostatectomy a rising PSA level almost always precedes clinical recurrence of carcinoma [107] 
The clinical significance of pre-treatment serum PSA values studied by Kuriyama et al [108] revealed that serum PSA can be used to predict the stage and prognosis of prostate cancer. Specifically, preoperative serum PSA levels are highly predictive of risk of recurrence after radical prostatectomy [109].

Determination of the serum urine PSA ratio enhances the specificity of PSA in screening, and in monitoring of patients with prostate cancer under androgen deprivation therapy [110]. An interesting study by D'Amico et al [111] revealed that men whose PSA level increases by more than $2.0 \mathrm{ng}$ per millilitre during the year before the diagnosis of prostate cancer may have a relatively high risk of death of prostate cancer despite having undergone radical prostatectomy. Pre-treatment PSA level of $20 \mathrm{ng} / \mathrm{ml}$ or above, is of predictive value for the survival of men with clinically localized prostate cancer. Whether models based on pretreatment PSA are as useful for predicting long-term survival as the other prognosticators like Gleason score, pathological lymph node status, and tumour stage will require further studies of longer follow-up to determine [112].

\section{Microvessel density (MVD)}

Tumour growth beyond a certain size requires angiogenesis. Once the tumour leaves the pre-angiogenic phenotype to become angiogenic, also metastases often start to evolve. Evaluation of the formation of new blood vessels has been proposed to provide important prognostic information in prostate cancer. The microvessel density count in the tumour area significantly increased with increasing Gleason score and nuclear grade. However, corresponding significant increase was not observed in the adjacent benign prostate or area of prostatic intraepithelial neoplasia (PIN) in the same samples [113]. Hall et al [114] concluded that quantification of tumour angiogenesis might prove valuable as a negative prognostic indicator in patients with localized prostate cancer. Borre et al [115] demonstrated that MVD was a significant predictor of shorter disease-specific survival in the entire cancer population as well as in the clinically localized cancer population. Halvorsen et al [116] concluded that in moderately differentiated prostatic adenocarcinoma MVD might improve the prognostic stratification of patients after radical prostatectomy. In contrast to these results, other studies $[117,118]$, suggested that MVD (vessels marked by CD31) is not a useful prognostic indicator for men with clinically localized prostate cancer. Gettman et al [119] concluded that MVD assessed by both OMVD (optimized microvessel density) and AWMVD (area-weighted microvessel density) did not predict recurrence of pathologic stage T3 adenocarcinoma of prostate. Microvessel density does not seem to be a prognosticator of disease-specific survival as compared to conventional pathology combined with p53 and retinoblastoma assessment [120].

\section{p53}

Mutations of the p53 tumour suppressor gene can result in uninhibited cellular growth and have been implicated in numerous malignancies [121]. In most human cancers, increased immunohistochemical expression is associated with point mutations in one allele of p53 gene and loss in the other. Thomas et al [122] and Shurbaji et al [123] evaluated the immunohistochemical detection of p53 protein in prostate cancer and its utility as a prognostic indicator. They concluded that mutations of p53 gene, which have long half-life, are involved in carcinogenesis of prostate cancer, and that $\mathrm{p} 53$ reactivity marks an aggressive subset of prostate cancer. To compare potential biologic markers with laboratory, clinical and histopathologic parameters and PSA level, tumour stage, tumour grade, and DNA content, Papadopoulos et al [103] characterized the proliferation marker Ki-S5, p53 expression, and ploidy status as potential tumour biomarkers. High values of these markers in immunohistochemistry reflected poor prognosis.

Protein expression of p53, Ki-67, and bcl2 were evaluated in archival paraffin-embedded radical prostatectomy specimens from 162 patients of clinically localized cancer by Moul et al [124] to determine the clinical use of p53, Ki-67, and bcl 2 immunohistochemical protein expression in the primary tumour as combined predictors of disease progression. The study concluded that p53, Ki-67, and bcl2 have potential as biomarkers to predict recurrence in patients with clinically localized prostate cancer after radical prostatectomy. All three markers were clearly correlated with recurrence estimates at 6 years. The same conclusion was obtained by Bauer et al [125].

Grignon et al [126] studied 471 patients to assess the prognostic value of identifying abnormal p53 protein expression in tumours of patients with locally advanced prostate cancer who were treated with either externalbeam radiation therapy alone, or total androgen blockade before and during the radiation therapy. Statistically significant associations were found between the presence of abnormal p53 protein expression and increased incidence of distant metastases, decreased progression-free survival, and decreased overall survival. Among patients receiving both radiation therapy and hormone therapy, those with tumours exhibiting abnormal p53 protein expression experienced a reduced time to the development of distant metastases.

Seventy-one patients with clinically localized prostate cancer treated with radical prostatectomy were assessed by Theodorescu et al [127] to investigate whether the levels of immunoreactivity for $\mathrm{p} 53, \mathrm{Rb}$, and $\mathrm{bcl} 2$ are better predictors of disease specific survival than conventional pathological parameters of the primary tumour, such as Gleason's score, capsular penetration, seminal vesicle 
invasion and percent of tumour in the specimen. They found that high level staining of p53 and Rb are independent factors predicting disease specific survival better than low level staining. They concluded that p53 and Rb immunohistochemical staining scores were superior to conventional pathological prognostic factors of the primary tumour as predictors of disease specific survival. In multivariate analysis, p53 overexpression was identified as the only prognostic parameter for recurrence-free survival $(\mathrm{P}=0.005)$ [128]. Further prospective studies are recommended to confirm the independent prognostic potential of p53 overexpression in patients with localised prostate cancer, but it seems that p53 expression has the potential to become a dominant prognosticator in clinical practice.

Scherr et al [129] evaluated the expression of two key regulators of apoptosis, bcl2 and p53, by immunohistochemical staining on pre-treatment needle biopsies from 54 patients who were later treated with radiotherapy for localized prostate cancer. They found that biopsies with positive bcl2 and p53 expression were associated with treatment failure after external beam radiation therapy. These finding suggested that determination of bcl2 and p53 expression in pre-treatment stage may be helpful for predicting response to definitive radiotherapy.

\section{p27}

p27 is an inhibitor of the cell cycle with potential tumour suppressor function; it belongs to the Cip/Kip family of cyclin-dependent kinase inhibitory proteins which down regulate cell proliferation. Decreased levels of p27 protein expression have been correlated with poor prognosis in patients with breast [130,131], lung [132], and ovarian cancers [133].

To evaluate the prognostic value of $\mathrm{p} 27$ protein levels in patients with localized prostate cancer, Yang et al [134] examined 86 patients with clinical stage T1-2 prostate cancer who were treated with radical prostatectomy. The archival paraffin embedded specimens were sectioned and immunostained with p27 antibody, and scored by two independent observers in a blind fashion. They found that absent or low levels of p27 protein expression were an adverse prognostic factor in patients with clinically organ confined disease. This marker appears to be especially useful in patients with pathological stage T2-T3b disease.

\section{p2I}

p21/WAF1 protein is a cyclin-dependent kinase inhibitor able to arrest the cell cycle at the G1 phase by inhibiting DNA replication. To understand the molecular mechanism leading to androgen-independent growth in prostate cancer, Baretton et al [135] demonstrated that p21/WAF1 overexpression before and after androgen deprivation therapy (ADT) characterized a subgroup of advanced prostate cancer with paradoxically high proliferation rate. Overexpressing cancers had significantly worse clinical outcome than cancers with low expression level.

Another type of p21 (ras p21) was studied by Agnantis et al [136]. They showed that ras p21 is detected in benign and cancerous lesions of the prostate gland. The expression tends to be weak in adenomatous hyperplasia and more intense in cancer. They found an inverse relation between ras p21 positivity and the degree of differentiation. The follow up of this study revealed a statistically significant correlation between 5-year survival and p21 expression, more intense staining reflecting poor survival.

\section{DNA ploidy}

\section{DNA content}

The first report on the relationship of DNA ploidy of prostate carcinoma with prognosis appeared in 1966 [137]. It has been suggested that cytological smear preparations are more suitable than tissue sections for determination of DNA content and morphometric parameters such as nuclear shape, size, and texture due to less overlap between cells and between cell nuclei [138].

DNA studies have shown that patients with diploid cancers have longer disease-free interval and survival times than those with non-diploid tumours [139]. However, they may not be so helpful in predicting stage for an individual patient. In a multivariate analysis Forsslund et al [140] showed that DNA ploidy was a better predictor of survival than histological grade and tumour stage. Frankfurt and his colleagues [141] examined 45 patients with prostate cancer and noted that all 11 patients with organ confined cancer had diploid tumours. None of the aneuploid tumours were organ confined. Blute et al [142] selected two equal groups of age-matched patients for study. The patients were followed for 5-21 years with a median follow-up of 8 years. Both groups initially had clinical and pathologic stage B disease and were treated uniformly by radical surgery without adjuvant therapy. Members of one group had disease progression, whereas members of the other group did not. Although tumour grade, capsular involvement, the number of tumour foci, and tumour volume were evaluated in addition to DNA ploidy, disease progression showed a significant relationship with ploidy only. In the group with disease progression, 37\% had diploid tumours, and 63\% had nondiploid tumours (of which 34\% tetraploid and 29\% aneuploid). In contrast, the group without progression had $92 \%$ diploid tumours, and 8\% non-diploid tumours (all tetraploid). 
The most convincing evidence of the prognostic role of DNA content comes from a study by Forsslund and Zetterberg [143] where DNA was measured in a series of patients with a long-term follow-up. Patients who died within 3 years of diagnosis consistently had DNA stemlines at $3 c$ and $6 c$, whereas long-term survivors (> 15 years) had stemlines at 2c and 4c. Stephenson et al [144] examined the ploidy value of cancer found in pelvic lymph node metastases and observed a strong correlation between mean survival time and ploidy status. In the Mayo Clinic prostatectomy series, ploidy was one of the significant predictive factors found in multivariate analysis of tumour characteristics [145].

The long-term outcome of 790 patients with adenocarcinoma of prostate treated with radical prostatectomy and early androgen ablation was assessed retrospectively by Seay and co-workers [146]. They found that diploid tumours were less likely to have biochemical (PSA test), local or systemic progression than non-diploid tumours. They concluded that patients with diploid tumours had a more favourable outcome than those with non-diploid tumours when treated with androgen ablation therapy. Ross et al [147] used needle biopsies for prediction of pathological stage and disease recurrence after prostatectomy by DNA ploidy analysis. The study showed a tenfold increase in risk for metastasis and three-fold risk for extra-capsular spread if the initial needle biopsy demonstrated non-diploidy. The authors concluded that ploidy analysis was more important than grade in prediction of outcome.

In a study of stage C prostate cancer, Lee S et al [148] found that there was a greater likelihood for recurrent disease after surgery if tumours were non-diploid. The probability of a disease-free interval of 60 months was $85 \%$ for those with diploid tumours as compared with only $9 \%$ for those with non-diploid tumours. This advantage held even in the presence of seminal vesicle involvement: $73 \%$ of patients with diploid tumours and seminal vesicle involvement remained free of disease during follow-up, as compared with only $8 \%$ of those who had non-diploid cancer and seminal vesicle involvement.

Buhmeida et al [149] studied the influences of sampling rules on the appearance of histograms in fine needle aspiration biopsies of prostate. He found that diploid or peridiploid patterns were commonly found in cell groups while tetraploid, peritetraploid, or aneuploid patterns were clearly more common among free cells. The results strongly suggested that measurements on cell groups were less efficient in detecting abnormality than the measurements done on free cells. The clinical relevance of the histogram patterns were also examined [150] with respect to their significance in differentiating between benign and malignant cells and also in estimating the stable or progressive character of prostate cancer. The aneuploidy patterns and DNA histogram characteristics defined by the presence of cells above cut-off points of $>5 c,>6 c,>7 c$ and $>8 \mathrm{c}$ seem to be useful in differentiation between the stable and progressive characteristics of cancer, i.e. between the more aggressive types of cancer and cancers with slower progressive activity.

\section{Cell proliferation}

\section{Ki-67}

$\mathrm{Ki}-67$ is one of several cell-cycle-regulating proteins, which can be demonstrated by immunohistochemistry $[151,152]$. It is a DNA-binding protein, which is expressed in all phases of cell cycle but undetectable in resting cells $[153,154]$. Ki-67 index (fraction of Ki-67 positive nuclei in immunohistochemistry) was higher for carcinomas than for hyperplastic glands. Within the group of carcinomas, Ki-67 indices in patients with metastatic disease were significantly higher than in those without metastasis. However, the results suggested that high Ki-67 index could define a group of patients with poor prognosis [155].

To identify associations between proliferative indexes (including Ki-67 index) and disease progression following radical prostatectomy, paraffin embedded specimens from 180 patients were immunohistochemically stained for Ki-67 antigen by Bettencourt and his colleagues [156]. They found that patients with a high Ki-67 antigen score had earlier progression and a lower 5-year recurrence-free survival rate than those with low or negative Ki-67 antigen score $(\mathrm{p}<0.001)$. The same was concluded by Bubendorf et al [157]. The results of a study by Aaltomaa et al [158] showed that Ki-67 expression is a potentially useful predictor of survival $(\mathrm{p}=0.025)$ in prostatic adenocarcinoma. In contrast to these studies, Ojea Calvo et al [159] suggested that Ki-67 expression (3\%) in preoperative biopsies is less effective than classic factors such as PSA, Gleason score, and pT classification in predicting prostate cancer biochemical progression after radical prostatectomy.

\section{S-phase fraction}

S-phase fraction (SPF) is the proportion of cells in the S phase of the cell cycle. S-phase fraction can be estimated from DNA flow cytometry (FC) histograms and also from DNA static cytometry histograms [160]. The results based on these two methods to evaluate proliferation parameters generally give similar results $[161,162]$. Although that some differences may exist. High SPF is associated with shorter overall survival and shorter time to local progression and metastasis in clinically localized prostate cancer [163]. Bratt et al [164] compared the prognostic significance of S-phase fraction with chromosome aberrations 
and DNA ploidy in prostate adenocarcinoma. They found that SPF as determined with FC was superior to karyotype and ploidy in predicting poor survival in prostate cancer.

\section{Gene expression profiling}

DNA microarray technology is revolutionizing the way fundamental biologic questions are addressed in the postgenomic era. Microarrays allow a simultaneous gene expression analysis of thousands of genes, providing an expression profile of the specimen investigated. The idea is to find gene expression profiles associated with good or poor clinical outcome in terms of survival or in terms of treatment response in prostate cancer $[165,166]$. The progress in this field has been shown particularly in breast cancer $[167,168]$. The use of a microarray based prognostic tool in prostate cancer is under development. However, some studies have implemented high-density DNA microarrays to analyze prostate cancer specimens [169171]. Gene expression profiles of invasive and organ-confined prostate cancer have been established [172], as these have been correlated with clinical behaviour [173].

\section{Conclusion}

The majority of prostate carcinomas never progress to clinically significant disease. A minor fraction of the clinical cases remains confined to the prostate for many years and other carcinomas progress rapidly to a life threatening disease. How to distinguish these three biologically different types [174], is a question of great importance. Pathologists play an important role in preoperative diagnosis and in the postoperative prognostic evaluation. Most research results currently available were based on radical prostatectomy specimens to find markers on the basis of disease progression could be predicted. This means that they need to be tested on biopsy material before the treatment decision to be taken. But the multifocal and heterogeneous nature of prostate cancer makes it difficult to obtain a representative biopsy sample. Improvements in biopsy procedures will be mandatory in order to make progress on this issue $[175,176]$.

Histological grading is a very important factor for the assessment of prognosis. Although the reproducibility is not perfect, still the Gleason's grading system is the most favoured prognostic factor, and highly significantly associated with survival and/or progression. Additionally, the volume of the tumour, vascular invasion, extension of the tumour through the prostate capsule, and invasion to the seminal vesicle might be valid prognostic factors for disease progression and survival. The value of different biomarkers (p53, ki-67, androgen receptor mutations, IGF, E-cadherin) remains to be applied in clinical practice $[171,177,178]$.
DNA ploidy is a good prognostic factor after prostatectomy and can be used in planning therapy. Unfortunately DNA ploidy measurements from biopsies are rare in clinical practice, in spite of the extensive literature that supports their use [173]. Compound prognostic factors based on the gene expression profiles (tested by DNA arrays) are promising and will accelerate the discovery of new predictive and prognostic molecules, but clinically relevant data up to this moment are still lacking [179]. Multivariate analyses of prognostic factors are enough, and multivariate models for prediction of compound prognosticators or predictors have not been well tested in clinical practice.

Approximately one third of clinically localized prostate cancer treated by radical prostatectomy will recur within 10 years. To prevent recurrence, new adjuvant therapies are in development for treating high-risk patients after surgery [180-182]. To identify good candidates for these treatments, there is still a need for new biomarkers that potentially will improve the ability of evaluation of the prognostic or predictive status of the patient [183].

\section{References}

I. Badalament RA, Drago JR: Prostate cancer. Dis Mon 199I, 37:199-268.

2. Hanchette CL, Schwartz GG: Geographic patterns of prostate cancer mortality. Evidence for a protective effect of ultraviolet radiation. Cancer 1992, 70:286I-2869.

3. Greenlee RT, Hill-Harmon MB, Murray T, Thun M: Cancer statistics, 200 I. CA Cancer J Clin 200I, 5 I(I): I5-36.

4. Shi XB, Gumerlock PH, deVere White RW: Molecular biology of prostate cancer. World J Urol 1996, I4:318-328.

5. Vogel W, Maier C, Paiss T: Prostate cancer. Cooper DN (editor) 2003, 4:743-757.

6. Foley R, Hollywood D, Lawler M: Molecular pathology of prostate cancer: the key to identifying new biomarkers of disease. Endocr Relat Cancer 2004, I I (3):477-88.

7. Paris PL, Andaya A, Fridlyand J, et al.: Whole genome scanning identifies genotypes associated with recurrence and metastasis in prostate tumours. Hum Mol Genet 2004, I 3:1303-13 I3.

8. Huncharek M, Muscat J: Genetic characteristics of prostate cancer. Cancer Epidemiol Biomarkers Prev 1995, 4:681-687.

9. Nupponen N, Visakorpi T: Molecular cytogenetics of prostate cancer. Microsc Res Tech 2000, 5 I:456-463.

10. Pan Y, Lui W, Nupponen N, Larsson C, Isola J, Visakorpi T, Bergerheim U, Kytola S: 5 q I I, 8p I I and I 0q22 are recurrent chromosomal breakpoints in prostate cancer cell lines. Genes Chromosomes Cancer 200I, 30: 187-195.

II. McNeal JE, Bostwick DG, Kindrachuk RA, Redwine EA, Freiha FS, et al.: Patterns of progression in prostate cancer. Lancet 1986, I:60-63.

12. Carter HB, Partin AW, Coffey DS: Prediction of metastatic potential in an animal model of prostate cancer: flow cytometric quantification of cell surface charge. J Urol 1989, |42(5): | 338-| $34 \mid$.

13. Kwast, van der TH: Prognostic factors and reporting of prostate carcinoma in radical prostatectomy specimens. Update in pathology. European Congress of Pathology,. 3-8 Sept, 2005 Paris :475-478.

14. Smith JA Jr, Cho $\mathrm{YH}$ : Management of stage A prostate cancer. Urol Clin North Am 1990, 17:769-777.

15. Austin JP, Convery K: Age race interaction in prostatic adenocarcinoma treated with external beam irradiation. Am J Clin Oncol 1993, 16:140-145.

16. Gronberg H, Damber JE, Jonsson H, Lenner P: Patient age as a prognostic factor in prostate cancer. J Urol 1994, I 52:892-895.

17. Herold DM, Hanlon AL, Movsas B, Hanks GE: Age-related prostate cancer metastases. Urology 1998, 5 I :985-990. 
18. Obek C, Lai S, Sadek S, Civantos F, Soloway MS: Age as a prognostic factor for disease recurrence after radical prostatectomy. Urology 1999, 54(3):533-538.

19. Freedland SJ, Presti JC, Kane CJ, Aronson WJ, Terris MK, Dorey F, et al.: Do younger men have better biochemical outcomes after radical prostatectomy? Urology 2004, 63(3):5 I 8-22.

20. Partin AW, Epstein Jl, Cho KR, Gittelsohn AM, Walsh PC: Morphometric measurement of tumour volume and per cent of gland involvement as predictors of pathological stage in clinical stage B prostate cancer. J Urol | 989, | 4 I:34| -345.

21. Terris MK, McNeal JE, Stamey TA: Estimation of prostate cancer volume by transrectal ultrasound imaging. I Urol 1992, | 47:855-857.

22. Dietrick DD, McNeal JE, Stamey TA: Core cancer length in ultrasound-guided systematic sextant biopsies: a preoperative evaluation of prostate cancer volume. Urology 1995, 45:987-992.

23. Terris MK, Haney DJ, Johnstone IM, McNeal JE, Stamey TA: Prediction of prostate cancer volume using prostate-specific antigen levels, transrectal ultrasound, and systematic sextant biopsies. Urology 1995, 45:75-80.

24. McNeal JE, Villers AA, Redwine EA, Freiha FS, Stamey TA: Capsular penetration in prostate cancer. Significance for natural history and treatment. Am J Surg Pathol 1990, I 4:240-247.

25. Epstein JI, Carmichael M, Partin AW, Walsh PC: Is tumour volume an independent predictor of progression following radica prostatectomy? A multivariate analysis of 185 clinical stage $B$ adenocarcinomas of the prostate with 5 years of followup. J Urol 1993, |49:|478-|48|

26. Bostwick DG, Graham SD, Napalkov P, Abrahamsson PA, di Sant'agnese PA, Algaba F, et al.: Staging of early prostate cancer: a proposed tumour volume-based prognostic index. Urology 1993, 41:403-41 I.

27. McNeal JE, Bostwick DG, Kindrachuk RA, Redwine EA, Freiha FS, Stamey TA: Patterns of progression in prostate cancer. Lancet 1986, I:60-63.

28. Salomon L, Levrel O, Anastasiadis AG, Irani J, De La Taille A, Saint F, et al.: Prognostic significance of tumour volume after radical prostatectomy: a multivariate analysis of pathological prognostic factors. Eur Urol 2003, 3( I):39-44

29. Kikuchi E, Scardino PT, Wheeler TM, Slawin KM, Ohori M: Is tumour volume an independent prognostic factor in clinically localized prostate cancer? J Urol 2004, I 72(2):508-I I

30. Bostwick DG: Grading prostate cancer. Am J Clin Pathol I994, I 02(I):S38-56.

31. Gleason DF: Classification of prostatic carcinomas. Cance Chemother Rep 1966, 50(3): I25-8.

32. Humphrey PA: Gleason grading and prognostic factors in car cinoma of the prostate. Mod Pathol 2004, I 7(3):292-306.

33. Bostwick DG: Grading prostate cancer. Am J Clin Pathol 1994, I 02(4 SuppI I):S38-56

34. Humphrey PA: Gleason grading and prognostic factors in car cinoma of the prostate. Mod Pathol 2004, I 7(3):292-306.

35. Djavan B, Kadesky K, Klopukh B, Marberger M, Roehrborn CG: Gleason scores from prostate biopsies obtained with I8 gauge biopsy needles poorly predict Gleason scores of radical prostatectomy specimens. Eur Urol 1998, 33:26I-270.

36. Lattouf JB, Saad F: Gleason score on biopsy: is it reliable for predicting the final grade on pathology? BJU Int 2002, 90(7):694-8.

37. Koksal IT, Ozcan F, Kadioglu TC, Esen T, Kilicaslan I, Tunc M: Discrepancy between Gleason scores of biopsy and radical prostatectomy specimens. Eur Urol 2000, 37:670-674

38. Shen BY, Tsui KH, Chang PL, Chuang CK, Hsieh ML, Huang ST, et al.: Correlation between the Gleason scores of needle biopsies and radical prostatectomy specimens. Chang Gung Med J 2003, 26(12):919-24.

39. Epstein Jl, Steinberg GD, The significance of low-grade prostate cancer on needle biopsy: A radical prostatectomy study of tumour grade, volume, and stage of the biopsied and multifocal tumour. Cancer 1990, 66:1927-1932.

40. Gleason DF, The veterans adminstrative cooperative urologic research group: Histological grading and clinical staging of prostatic carcinoma. Urologic Pathology: The prostate. Philadelphia: Lea and Febiger 1977: 171-198.
41. Sogani PC, Israel A, Lieberman PH, Lesser ML, Whitmore WF: Gleason grading of prostate cancer: a predictor of survival. Urology 1985, 25:223-227.

42. Rioux-Leclercq NC, Chan DY, Epstein Jl: Prediction of outcome after radical prostatectomy in men with organ-confined Gleason score 8 to 10 adenocarcinoma. Urology 2002, 60(4):666-9.

43. Cheng L, Koch MO, Juliar BE, Daggy JK, Foster RS, Bihrle R, Gardner TA: The combined percentage of Gleason patterns $\mathbf{4}$ and 5 is the best predictor of cancer progression after radical prostatectomy. J Clin Oncol 2005, 23( I3):291 I-7.

44. Partin AW, Yoo J, Carter HB, Pearson JD, Chan DW, Epstein J Walsh PC: The use of prostate specific antigen, clinical stage and Gleason score to predict pathological stage in men with localized prostate cancer. J Urol 1993, I 50(I): I 10-4.

45. Oesterling JE, Brendler CB, Epstein JI, Kimball AW, Walsh PC: Correlation of clinical stage, serum prostatic acid phosphatase and preoperative Gleason grade with final pathological stage in $\mathbf{2 7 5}$ patients with clinically localized adenocarcinoma of the prostate. J Urol 1987, I 38:92-98.

46. Fowler JE, Mills SE: Operable prostatic carcinoma: correlations among clinical stage, pathological stage, gleason histological score and early disease-free survival. J Urol 1985, I33:49-52.

47. Epstein JI, Carmichael M, Walsh PC: Adenocarcinoma of the prostate invading the seminal vesicle: definition and relation of tumour volume, grade and margins of resection to prognosis. J Urol 1993, I49:1040-1045.

48. Theiss M, Wirth MP, Manseck A, Frohmuller HG: Prognostic significance of capsular invasion and capsular penetration in patients with clinically localized prostate cancer undergoing radical prostatectomy. Prostate 1995, 27:13-17.

49. Ohori M, Wheeler TM, Kattan MW, Goto Y, Scardino PT: Prognostic significance of positive surgical margins in radical prostatectomy specimens. J Urol 1995, I 54:1818-1824.

50. Wheeler TM, Dillioglugil O, Kattan MW, Arakawa A, Soh S, Suyama $K$, et al.: Clinical and pathological significance of the level and extent of capsular invasion in clinical stage TI-2 prostate cancer. Hum Pathol 1998, 29:856-862.

5I. Deliveliotis CH, Varkarakis J, Trakas N, Louras G, Giannakopoulos S, Skolarikos A, et al:: Influence of preoperative vesicle biopsy on the decision for radical prostatectomy. Int Urol Nephrol 1999, 3 I:83-87.

52. Salomon L, Anastasiadis AG, Johnson CW, McKiernan JM, Goluboff $E T$, Abbou CC, et al.: Seminal vesicle involvement after radical prostatectomy: predicting risk factors for progression. Urology 2003, 62(2):304-9.

53. Epstein Jl, Carmichael MJ, Pizov G, Walsh PC: Influence of capsular penetration on progression following radical prostatectomy: a study of 196 cases with long-term followup. J Urol 1993, I50:135-14|.

54. Bloom KD, Richie JP, Schultz D, Renshaw A, Saegaert T, D'amico AV: Invasion of seminal vesicles by adenocarcinoma of the prostate: PSA outcome determined by preoperative and postoperative factors. Urology 2004, 63(2):333-6.

55. Debras B, Guillonneau B, Bougaran J, Chambon E, Vallancien G: Prognostic significance of seminal vesicle invasion on the radical prostatectomy specimen. Rationale for seminal vesicle biopsies. Eur Urol 1998, 33:271-277.

56. Freedland SJ, Aronson WJ, Presti JC, Amling CL, Terris MK, Trock B, et al.: Predictors of prostate-specific antigen progression among men with seminal vesicle invasion at the time of radical prostatectomy. Cancer 2004, I 5; I 00(8): 1633-8.

57. McNeal JE: Regional morphology and pathology of the prostate. Am / Clin Pathol 1968, 49:347-357.

58. McNeal J: The zonal anatomy of the prostate. Prostate 198I, 2:35-49.

59. McNeal JE, Redwine EA, Freiha FS, Stamey TA: Zonal distribution of prostatic adenocarcinoma. Correlation with histologic pattern and direction of spread. Am J Surg Pathol 1988, I 2:897-906.

60. Greene DR, Wheeler TM, Egawa S, Dunn JK, Scardino PT: A comparison of the morphological features of cancer arising in the transition zone and in the peripheral zone of the prostate. Urol 1991, 146:1069-1076.

6I. Augustin H, Hammerer PG, Blonski J, Graefen M, Palisaar J, Daghofer $F$, et al.: Zonal location of prostate cancer: significance for dis- 
ease-free survival after radical prostatectomy? Urology 2003 , 62(I):79-85

62. Jack GS, Cookson MS, Coffey CS, Vader V, Roberts RL, Chang SS, et al.: Pathological parameters of radical prostatectomy for clinical stages TIc versus T2 prostate adenocarcinoma: decreased pathological stage and increased detection of transition zone tumours. J Urol 2002, 168(2):5| 9-24.

63. Moore RA: Morphology of small prostatic carcinomas. J Urol 1935, 33:224-235.

64. Miller GJ, Cygan JM: Diagnostic correlations with whole mounts of radical prostatectomy specimens. Monogr Pathol 1992, 34: $183-197$.

65. Murphy GP, Busch C, Abrahamsson PA, Epstein JI, McNeal JE, Miller G], et al.: Histopathology of localized prostate cancer. Consensus Conference on Diagnosis and Prognostic Parameters in Localized Prostate Cancer. Scand J Urol Nephrol Suppl 1994, 162:12-13.

66. Verhagen PC, Tilanus MG, de Weger RA, van Moorselaar RJ, van den Tweel JG, Boon TA: Prognostic factors in localised prostate cancer with emphasis on the application of molecular techniques. Eur Urol 2002, 4 I (4):363-7I.

67. Hammerer $P$, Huland $H$, Sparenberg A: Digital rectal examination, imaging, and systematic-sextant biopsy in identifying operable lymph node-negative prostatic carcinoma. Eur Urol 1992, 22:28I-287.

68. Djavan B, Susani M, Bursa B, Basharkhah A, Simak R, Marberger M: Predictability and significance of multifocal prostate cancer in the radical prostatectomy specimen. Tech Urol 1999, 5(3): 139-42

69. Diamond DA, Berry SJ, Umbricht C, Jewett HJ, Coffey DS: Computerized image analysis of nuclear shape as a prognostic factor for prostatic cancer. Prostate 1982, 3(4):32I-32.

70. Diamond DA, Berry SJ, Jewett HJ, Eggleston JC, Coffey DS: A new method to assess metastatic potential of human prostate cancer: relative nuclear roundness. J Urol 1982, I 28:729-734.

71. Epstein Jl, Berry SJ, Eggleston JC: Nuclear roundness factor. A predictor of progression in untreated stage A2 prostate cancer. Cancer 1984, 54:666-67I.

72. Clark TD, Askin FB, Bagnell CR: Nuclear roundness factor: a quantitative approach to grading in prostatic carcinoma reliability of needle biopsy tissue, and the effect of tumour stage on usefulness. Prostate 1987, 10:199-206.

73. Eichenberger T, Mihatsch MJ, Oberholzer M, Gschwind R, Rutishauser G: Are nuclear shape factors good predictors of the disease course in patients with carcinoma of the prostate? Prog Clin Biol Res 1987, 243A:533-537.

74. Mohler JL, Partin AW, Epstein JI, Lohr WD, Coffey DS: Nuclear roundness factor measurement for assessment of prognosis of patients with prostatic carcinoma. II. Standardization of methodology for histologic sections. J Urol 1988, 139: 1085-1090.

75. Partin AW, Walsh AC, Pitcock RV, Mohler JL, Epstein JI, Coffey DS: A comparison of nuclear morphometry and Gleason grade as a predictor of prognosis in stage A2 prostate cancer: a critical analysis. J Urol 1989, I 42:1254-1258.

76. Partin AW, Steinberg GD, Pitcock RV, Wu L, Piantadosi S, Coffey DS, et al.: Use of nuclear morphometry, Gleason histologic scoring, clinical stage, and age to predict disease-free survival among patients with prostate cancer. Cancer 1992, 70:161-168.

77. Aragona F, Franco V, Rodolico V, Dardanoni G, Cabibi D, Melloni D, et al.: Interactive computerized morphometric analysis for the differential diagnosis between dysplasia and well differentiated adenocarcinoma of the prostate. Urol Res 1989, 17:35-40.

78. Vesalainen S, Lipponen P, Talja M, Kasurinen J, Syrjanen K: Nuclear morphometry is of independent prognostic value only in $\mathrm{TI}$ prostatic adenocarcinomas. Prostate 1995, 27: I 10-1 I7.

79. Martinez-Jabaloyas JM, Ruiz-Cerda JL, Hernandez M, Jimenez A, Jimenez-Cruz F: Prognostic value of DNA ploidy and nuclear morphometry in prostate cancer treated with androgen deprivation. Urology 2002, 59(5):715-20.

80. Martinez Jabaloyas JM, Jimenez Sanchez A, Ruiz Cerda JL, Sanz Chinesta S, Sempere A, Jimenez Cruz JF: Prognostic value of DNA ploidy and nuclear morphometry in metastatic prostate cancer. Actas Urol Esp 2004, 28(4):298-307.
8I. Maffini MV, Ortega HH, Stoker C, Giardina RH, Luque EH, Munoz de Toro MM: Bcl-2 correlates with tumour ploidy and nuclear morphology in early stage prostate carcinoma. fine needle aspiration biopsy study. Pathol Res Pract 200I, 197(7):487-92.

82. Buhmeida A, Kuopio T, Collan Y: Nuclear size and shape in fine needle aspiration biopsy samples of the prostate. Anal Quant Cytol Histol 2000, 22(4):291-8.

83. Umbas R, Schalken JA, Aalders TW, Carter BS, Karthaus HF, Schaafsma $\mathrm{HE}$, et al:: Expression of the cellular adhesion molecule E-cadherin is reduced or absent in high-grade prostate cancer. Cancer Res 1992, 52:5104-5109.

84. Umbas R, Isaacs WB, Bringuier PP, Schaafsma HE, Karthaus HF, Oosterhof GO, et al.: Decreased E-cadherin expression is associated with poor prognosis in patients with prostate cancer. Cancer Res 1994, 54:3929-3933.

85. Umbas R, Isaacs WB, Bringuier PP, Xue Y, Debruyne FM, Schalken JA: Relation between aberrant alpha-catenin expression and loss of E-cadherin function in prostate cancer. Int J Cancer 1997, 74:374-377.

86. Aaltomaa S, Lipponen $\mathrm{P}$, Ala-Opas M, Eskelinen M, Kosma VM: Alpha-catenin expression has prognostic value in local and locally advanced prostate cancer. BrJ Cancer 1999, 80:477-482.

87. De Marzo AM, Knudsen B, Chan-Tack K, Epstein Jl: E-cadherin expression as a marker of tumour aggressiveness in routinely processed radical prostatectomy specimens. Urology 1999, 53:707-7|3.

88. Rhodes DR, Sanda MG, Otte AP, Chinnaiyan AM, Rubin MA: Multiplex biomarker approach for determining risk of prostatespecific antigen-defined recurrence of prostate cancer. J Nat Cancer Inst 2003, 9:661-8.

89. Mita K, Nakahara M, Usui T: Expression of the insulin-like growth factor system and cancer progression in hormonetreated prostate cancer patients. Int J Urol 2000, 7:32I-329.

90. Figueroa JA, De-Raad S, Tadlock L, Speights VO, Rinehart J]: Differential expression of insulin-like growth factor binding proteins in high versus low Gleason score prostate cancer. J Urol 1998, 159:1379-1383.

9I. Yu H, Nicar MR, Shi R, Berkel HJ, Nam R, Trachtenberg J, et al.: Levels of insulin-like growth factor I (IGF-I) and IGF binding proteins 2 and 3 in serial postoperative serum samples and risk of prostate cancer recurrence. Urology 200I, 57:47I-475.

92. Mantzoros CS, Tzonou A, Signorello LB, Stampfer M, Trichopoulos $D$, Adami HO: Insulin-like growth factor I in relation to prostate cancer and benign prostatic hyperplasia. Br J Cancer I997, 76(9): $1115-8$

93. Chan JM, Stampfer MJ, Giovannucci E, Gann PH, Ma J, Wilkinson P, Hennekens $\mathrm{CH}$, Pollak M: Plasma insulin-like growth factor-I and prostate cancer risk: a prospective study. Science 1998 , 23;279(5350):563-6

94. Shariat SF, Bergamaschi F, Adler HL, Nguyen C, Kattan MW, Wheeler TM, et al: Correlation of preoperative plasma IGF-I levels with pathologic parameters and progression in patients undergoing radical prostatectomy. Urology 2000, 56:423-429.

95. Yu H, Bharaj B, Vassilikos EJ, Giai M, Diamandis EP: Shorter CAG repeat length in the androgen receptor gene is associated with more aggressive forms of breast cancer. Breast Cancer Res Treat 2000, 59:153-161

96. Koivisto P, Kolmer M, Visakorpi T, Kallioniemi OP: Androgen receptor gene and hormonal therapy failure of prostate cancer. Am J Pathol 1998, 152:1-9.

97. Wallen MJ, Linja M, Kaartinen K, Schleutker J, Visakorpi T: Androgen receptor gene mutations in hormone-refractory prostate cancer. J Pathol 1999, 189:559-563.

98. Segawa N, Mori I, Utsunomiya H, Nakamura M, Nakamura Y, Shan L, et al:: Prognostic significance of neuroendocrine differentiation, proliferation activity and androgen receptor expression in prostate cancer. Pathol Int 200 I, 5 I:452-459.

99. Miyoshi $Y$, Ishiguro $H$, Uemura $H$, Fujinami $K$, Miyamoto $H$, Miyoshi $Y$, et al.: Expression of AR associated protein 55 (ARA55) and androgen receptor in prostate cancer. Prostate 2003, I;56(4):280-6.

100. Culig Z, Hobisch A, Cronauer MV, Radmayr C, Trapman J, Hittmair $A$, et al.: Androgen receptor activation in prostatic tumour cell lines by insulin-like growth factor-I, keratinocyte growth factor, and epidermal growth factor. Cancer Res 1994, 15;54(20):5474-8. 
10I. Sadi MV, Barrack ER: Image analysis of androgen receptor immunostaining in metastatic prostate cancer. Heterogeneity as a predictor of response to hormonal therapy. Cancer | 993, 7 I:2574-2580.

102. Magi-Galluzzi C, Xu X, Hlatky L, Hahnfeldt P, Kaplan I, Hsiao P, et al.: Heterogeneity of androgen receptor content in advanced prostate cancer. Mod Pathol 1997, 10:839-845.

103. Papadopoulos I, Rudolph P, Wirth B, Weichert Jacobsen K: p53 expression, proliferation marker Ki-S5, DNA content and serum PSA: possible biopotential markers in human prostatic cancer. Urology 1996, 48:261-268.

104. Daher R, Beaini M: Prostate-specific antigen and new related markers for prostate cancer. Clin Chem Lab Med 1998, 36:67I-68I.

105. Björk T, Lilja $\mathrm{H}$, Christensson $\mathrm{A}$ : The prognostic value of different forms of prostate specific antigen and their ratios in patients with prostate cancer. BJU Int 1999, 84:102I-1027.

106. Zagars GK: Prostate-specific antigen as a prognostic factor for prostate cancer treated by external beam radiotherapy. Int J Radiat Oncol Biol Phys 1992, 23:47-53.

107. Pound CR, Partin AW, Eisenberger MA, Chan DW, Pearson JD, Walsh PC: Natural history of progression after PSA elevation following radical prostatectomy. JAMA I999, 5;28 I ( I7): I59|-7.

108. Kuriyama M, Obata K, Miyagawa Y, Nishikawa E, Koide T, Takeda A, et al: Serum prostate-specific antigen values for the prediction of clinical stage and prognosis in patients with prostate cancer: an analysis of 749 cases. Int J Urol 1996, 3:462-467.

109. Hull GW, Rabbani F, Abbas F, Wheeler TM, Kattan MW, Scardino PT: Cancer control with radical prostatectomy alone in 1,000 consecutive patients. J Urol 2002, 167(2):528-34.

1 10. Hellenbrand M, Bastian M, Steiner M, Zingler C, Muller M, Wolff J, et al.: Serum to urinary prostate specific antigen ratio in patients with benign prostatic hyperplasia and prostate cancer. Anticancer Res 2000, 20:4995-4996.

III. D'Amico AV, Chen MH, Roehl KA, Catalona WJ: Preoperative PSA velocity and the risk of death from prostate cancer after radical prostatectomy. N Engl | Med 2004, 35 I: I 25-35

II2. Roach M, Lu J, Pilepich MV, Asbell SO, Mohiuddin M, Terry R, et al: Four prognostic groups predict long-term survival from prostate cancer following radiotherapy alone on Radiation Therapy Oncology Group clinical trials. Int J Radiat Oncol Biol Phys 2000, 1;47:609-6I5.

1 13. Bettencourt MC, Bauer JJ, Sesterhenn IA, Connelly RR, Moul JW: CD34 immunohistochemical assessment of angiogenesis as a prognostic marker for prostate cancer recurrence after radical prostatectomy. J Urol 1998, 160:459-465.

1 14. Hall MC, Troncoso P, Pollack A, Zhau HY, Zagars GK, Chung LW, et al.: Significance of tumour angiogenesis in clinically localized prostate carcinoma treated with external beam radiotherapy. Urology 1994, 44:869-875.

II5. Borre M, Offersen BV, Nerstrom B: Overgaard J. Microvessel density predicts survival in prostate cancer patients subjected to watchful waiting. Br J Cancer 1998, 78:940-944

I 16. Halvorsen O, Haukaas S, Hoisaeter P, Akslen L: Independent prognostic importance of microvesel density in clinically localized prostate cancer. Anticancer Res 2000, 20:379|-3799.

117. Rubin MA, Buyyounouski M, Bagiella E, Sharir S, Neugut A, Benson M, et al: Microvessel density in prostate cancer: lack of correlation with tumour grade, pathologic stage, and clinical outcome. Urology 1999, 53:542-547.

118. Strohmeyer D, Rossing C, Strauss F, Bauerfeind A, Kaufmann $O$ Loening S: Tumour angiogenesis is associated with progression after radical prostatectomy in $\mathrm{PT} 2 / \mathrm{pT} 3$ prostate cancer. Prostate 2000, 42:26-33.

119. Gettman MT, Pacelli A, Slezak J, Bergstralh EJ, Blute M, Zincke H, Bostwick DG: Role of microvessel density in predicting recurrence in pathologic Stage T3 prostatic adenocarcinoma. Urology 1999, 54:479-485.

120. Krupski T, Petroni GR, Frierson HF Jr, Theodorescu JU: Microvessel density, p53, retinoblastoma, and chromogranin $A$ immunohistochemistry as predictors of disease-specific survival following radical prostatectomy for carcinoma of the prostate. Urology 2000, 55:743-749.

121. Stricker HJ, Jay JK, Linden MD, Tamboli P, Amin MB: Determining prognosis of clinically localized prostate cancer by immuno- histochemical detection of mutant p53. Urology 1996, 47:366-369.

122. Thomas DJ, Robinson M, King P, Hasan T, Charlton R, Martin J, et al:: p53 expression and clinical outcome in prostate cancer. $\mathrm{Br}$ Urol 1993, 72:778-78।

123. Shurbaji MS, Kalbfleisch JH, Thurmond TS: Immunohistochemical detection of $\mathrm{p} 53$ protein as a prognostic indicator in prostate cancer. Hum Pathol 1995, 26:106-109.

124. Moul JW, Bettencourt MC, Sesterhenn IA, Mostofi FK, McLeod DG, Srivastava S, et al.: Protein expression of p53, bcl-2, and KI-67 (MIB-I) as prognostic biomarkers in patients with surgically treated, clinically localized prostate cancer. Surgery 1996, 120:159-166.

125. Bauer JJ, Sesterhenn IA, Mostofi FK, McLeod DG, Srivastava S, Moul $\mathrm{JW}$ : Elevated levels of apoptosis regulator proteins p53 and bcl-2 are independent prognostic biomarkers in surgically treated clinically localized prostate cancer. J Urol 1996, 156:1511-1516.

126. Grignon DJ, Caplan R, Sarkar FH, Lawton CA, Hammond EH, Pilepich $\mathrm{MV}$, et al:: $\mathbf{p} 53$ status and prognosis of locally advanced prostatic adenocarcinoma: a study based on RTOG 86I0. J Nat Cancer Inst 1997, 89: 158-165.

127. Theodorescu D, Broder SR, Boyd JC, Mills SE, Frierson HF: p53, bcl2 and retinoblastoma proteins as long-term prognostic markers in localized carcinoma of the prostate. J Urol 1997. I58:|3|-|37.

128. Kuczyk MA, Serth J, Bokemeyer C, Machtens S, Minssen A, Bathke W, et al: The prognostic value of $\mathrm{p} 53$ for long-term and recurrence-free survival following radical prostatectomy. Eur J Cancer 1998, 34:679-686.

129. Scherr DS, Vaughan ED, Wei J, Chung M, Felsen D, Allbright R, et al.: $B C L-2$ and $p 53$ expression in clinically localized prostate cancer predicts response to external beam radiotherapy. J Urol 1999, 162:12-16.

130. Barbareschi M: p27 Expression, a cyclin dependent kinase inhibitor in breast carcinoma. Adv Clin Path 1999, 3:1 19-127.

|3I. Tsuchiya A, Zhang G], Kanno M: Prognostic impact of cyclindependent kinase inhibitor p27kip 1 in node-positive breast cancer. J Surg Oncol 1999, 70(4):230-234.

132. Catzavelos C, Tsao MS, DeBoer G, Bhattacharya N, Shepherd FA, Slingerland JM: Reduced expression of the cell cycle inhibitor p27Kipl in non-small cell lung carcinoma: a prognostic factor independent of Ras. Cancer Res 1999, 59:684-688.

133. Masciullo V, Sgambato A, Pacilio C, Pucci B, Ferrandina G, Palazzo J, et al: Frequent loss of expression of the cyclin-dependent kinase inhibitor p27 in epithelial ovarian cancer. Cancer Res 1999, 59:3790-3794.

134. Yang RM, Naitoh J, Murphy M, Wang HJ, Phillipson J, deKernion JB, et al.: Low p27 expression predicts poor disease-free survival in patients with prostate cancer. JUrol 1998, 159:941-945.

135. Baretton GB, Klenk U, Diebold J, Schmeller N, Lohrs U: Proliferation and apoptosis associated factors in advanced prostatic carcinomas before and after androgen deprivation therapy: prognostic significance of $\mathbf{p} 2 \mathrm{I} / \mathrm{WAFI} / \mathrm{CIPI}$ expression. $\mathrm{Br}$ Cancer 1999, 80:546-55.

136. Agnantis NJ, Constantinidou AE, Papaevagelou M, Apostolikas N: Comparative immunohistochemical study of ras-p2I oncoprotein in adenomatous hyperplasia and adenocarcinoma of the prostate gland. Anticancer Res 1994, 14:2135-2|40.

137. Tavares AS, Costa J, Carvalho A, Reis M: Tumour ploidy and prognosis in carcinomas of the bladder and prostate. $\mathrm{Br} J$ Cancer 1966, 20:438-44|.

138. Epstein JI, Christensen WN, Steinberg GD, Carter HB: Comparison of DNA ploidy and nuclear size, shape and chromatin irreg. ularity in tissue sections and smears of prostatic carcinoma. Anal Quant Cytol Histol 1990, 1 2:352-358.

139. Zinke H, Larson Keller J]: Stage D I prostate cancer treated by RP and adjuvant hormonal treatment. Cancer 1992:3 I I-323.

140. Forsslund G, Esposti PL, Nilsson B, Zetterberg A: The prognostic significance of nuclear DNA content in prostatic carcinoma. Cancer 1992, 69:1432-1439.

14I. Frankfurt OS, Chin JL, Englander LS, Greco WR, Pontes JE, Rustum YM: Relationship between DNA ploidy, glandular differentiation, and tumour spread in human prostate cancer. Cancer Res 1985, 45: $1418-1423$ 
142. Blute ML, Nativ O, Zincke H, Farrow GM, Therneau T, Lieber MM: Pattern of failure after radical retropubic prostatectomy for clinically and pathologically localized adenocarcinoma of the prostate: influence of tumour deoxyribonucleic acid ploidy. J Urol 1989, 142: 1262-1265.

143. Forsslund G, Zetterberg A: Ploidy level determinations in highgrade and low-grade malignant variants of prostatic carcinoma. Cancer Res 1990, 50:428I-4285.

144. Stephenson RA, James BC, Gay H, Fair WR, Whitmore WF, Melamed MR: Flow cytometry of prostate cancer: relationship of DNA content to survival. Cancer Res 1987, 47:2504-2507.

145. Ward JF, Slezak JM, Blute ML, Bergstralh E, Zincke H: Radical prostatectomy for clinically advanced (cT3) prostate cancer since the advent of prostate-specific antigen testing: 15-year outcome. BJU Int 2005, 95:75I-756.

146. Seay TM, Blute ML, Zincke H: Long-term outcome in patients with pTxN+ adenocarcinoma of prostate treated with radical prostatectomy and early androgen ablation. J Urol 1998, I 59:357-364.

147. Ross JS, Figge $H$, Bui $H X$, del Rosario AD, Jennings TA, Rifkin MD, et al.: Prediction of pathologic stage and postprostatectomy disease recurrence by DNA ploidy analysis of initial needle biopsy specimens of prostate cancer. Cancer 1994, 74:28II-28I8

148. Lee SE, Currin SM, Paulson DF, Walther PJ: Flow cytometric determination of ploidy in prostatic adenocarcinoma: a comparison with seminal vesicle involvement and histopathological grading as a predictor of clinical recurrence. J Urol 1988, I 40:769-774.

149. Buhmeida A, Kuopio T, Collan Y: Influence of sampling practices on the appearance of DNA image histograms of prostate cells in FNAB samples. Anal Cell Pathol 1999, I 8(2):95-102.

150. Buhmeida A, Backman H, Collan Y: DNA cytometry in diagnostic cytology of the prostate gland. Anticancer Res 2002, 22(4):2397-402.

15I. Gerdes J, Schwab U, Lemke H, Stein H: Production of a mouse monoclonal antibody reactive with a human nuclear antigen associated with cell proliferation. Int J Cancer 1983, 31:13-20.

152. Cooper LS, Gillett CE, Smith P, Fentiman IS, Barnes DM: Cell proliferation measured by MIBI and timing of surgery for breast cancer. Br J Cancer 1998, 77:1502-1507.

153. Guillaud P, du Manoir S, Seigneurin D: Quantification and topographical description of $\mathrm{Ki}-67$ antibody labelling during the cell cycle of normal fibroblastic (MRC-5) and mammary tumour cell lines (MCF-7). Anal Cell Pathol 1989, I:25-39.

154. Gerdes J, Li L, Schlueter C, Duchrow M, Wohlenberg C, Gerlach C, et al.: Immunobiochemical and molecular biologic characterization of the cell proliferation-associated nuclear antigen that is defined by monoclonal antibody Ki-67. Am J Pathol I99I, I 38:867-873.

155. McLoughlin J, Foster CS, Price P, Williams G, Abel PD: Evaluation of $\mathrm{Ki}-67$ monoclonal antibody as prognostic indicator for prostatic carcinoma. $\mathrm{Br}$ J Urol 1993, 72:92-97.

156. Bettencourt MC, Bauer JJ, Sesterhenn IA, Mostofi FK, McLeod DG, Moul JW: Ki-67 expression is a prognostic marker of prostate cancer recurrence after radical prostatectomy. I Urol 1996, 156:1064-1068.

157. Bubendorf L, Sauter G, Moch H, Schmid HP, Gasser TC, Jordan P, et al.: Ki67 labelling index: an independent predictor of progression in prostate cancer treated by radical prostatectomy. J Pathol 1996, 178:437-44I.

158. Aaltomaa S, Lipponen P, Vesalainen S, Ala-Opas M, Eskelinen M, Syrjanen $\mathrm{K}$ : Value of $\mathrm{Ki}-67 \mathrm{immunolabelling}$ as a prognostic factor in prostate cancer. Eur Urol 1997, 3:2410-5.

159. Ojea Calvo A, Mosteiro Cervino MJ, Dominguez Freire F, Alonso Rodrigo A, Rodriguez Iglesias B, Benavente Delgado J, et al.: The usefulness of Ki67 expression in the biopsy specimens, to predict the biochemical progresion of the prostate cancer after radical prostatectomy. Acta Urol Esp 2004, 28:650-60.

160. Montironi R, Diamanti L, Santinelli A, Scarpelli M: Computer-aided S-phase fraction determination in DNA static cytometry in breast cancer. A preliminary methodologic study on cytologic material. Anal Quant Cytol Histol 1992, 14:379-385.

161. Quinn CM, Wright NA: The clinical assessment of proliferation and growth in human tumours: evaluation of methods and applications as prognostic variables. J Pathol 1990, 160:93-102.
162. Woosley JT: Measuring cell proliferation. Arch Pathol Lab Med 1991, I 1 5:555-557.

163. Astrom L, Weimarck A, Aldenborg F, Delle U, Hanson C, Verbiene I, et al:: S-phase fraction related to prognosis in localised prostate cancer. No specific significance of chromosome 7 gain or deletion of 7q3 I.I. Int J Cancer 1998, 79:553-559.

164. Bratt O, Anderson H, Bak Jensen E, Baldetorp B, Lundgren R: Metaphase cytogenetics and DNA flow cytometry with analysis of S-phase fraction in prostate cancer: influence on prognosis. Urology 1996, 47:218-224.

165. Singh D, Febbo PG, Ross K, Jackson DG, Manola J, Ladd C, et al:: Gene expression correlates of clinical prostate cancer behavior. Cancer Cell 2002, I(2):203-9.

166. Henshall SM, Afar DE, Hiller J, Horvath LG, Quinn DI, Rasiah KK, et al:: Survival analysis of genome-wide gene expression profiles of prostate cancers identifies new prognostic targets of disease relapse. Cancer Res 2003, 15;63(14):4196-203.

167. van 't Veer LJ, Dai H, van de Vijver MJ, He YD, Hart AA, Mao M, et al: Gene expression profiling predicts clinical outcome of breast cancer. Nature 2002, 3 I;415(687 I):530-6.

168. van de Vijver MJ, He YD, van't Veer LJ, Dai H, Hart AA, Voskuil DW, Schreiber GJ, et al.: A gene-expression signature as a predictor of survival in breast cancer. N Engl 」 Med 2002, 19;347(25): 1999-2009.

169. Dhanasekaran SM, Barrette TR, Ghosh D, Shah R, Varambally S, Kurachi K: Delineation of prognostic biomarkers in prostate cancer. Nature 200I, 23;4I 2(6849):822-6.

170. Magee JA, Araki T, Patil S, Ehrig T, True L, Humphrey PA, et al.: Expression profiling reveals hepsin overexpression in prostate cancer. Cancer Res 200I, I;6 I(15):5692-6.

17I. Ernst T, Hergenhahn M, Kenzelmann M, Cohen CD, Bonrouhi M, Weninger A, et al:: Decrease and gain of gene expression are equally discriminatory markers for prostate carcinoma: a gene expression analysis on total and microdissected prostate tissue. Am J Pathol 2002, 160(6):2169-80.

172. Luo JH, Yu YP, Cieply K, Lin F, Deflavia P, Dhir R, Finkelstein S, et al:: Gene expression analysis of prostate cancers. Mol Carcinog 2002, 33(I):25-35

173. Lapointe J, Li C, Higgins JP, van de Rijn M, Bair E, Montgomery K, et al.: Gene expression profiling identifies clinically relevant subtypes of prostate cancer. Proc Natl Acad Sci U S A 2004, 20;10I(3):8II-6.

174. Mikuz G: Pathology of prostate cancer. Old problems and new facts. Adv Clin Path 1997, I(I):2 I-34.

175. Buhmeida A, Collan Y: Improving the value of fine needle aspiration biopsy of the prostate. Pathologica 200I, 93(3):242-3.

176. Verhagen PC, Tilanus MG, de Weger RA, van Moorselaar RJ, van den Tweel JG, Boon TA: Prognostic factors in localised prostate cancer with emphasis on the application of molecular techniques. Eur Urol 2002, 4 I (4):363-7I.

177. Moul JW, Merseburger AS, Srivastava S: Molecular markers in prostate cancer: the role in preoperative staging. Clin Prostate Cancer 2002, I(I):42-50.

178. Quinn DI, Henshall SM, Sutherland RL: Molecular markers of prostate cancer outcome. Eur J Cancer 2005, 4I(6):858-87.

179. Quinn DI, Henshall SM, Sutherland RL: Molecular markers of prostate cancer outcome. Eur J Cancer 2005, 4 I (6):858-87.

180. De Marzo AM, Knudsen B, Chan-Tack K, Epstein Jl: E-cadherin expression as a marker of tumour aggressiveness in routinely processed radical prostatectomy specimens. Urology 1999, 53(4):707-13.

18I. Roscigno M, Sangalli M, Mazzoccoli B, Scattoni V, Da Pozzo L, Rigatti P: Medical therapy of prostate cancer. A review Minerva Urol Nefrol 2005, 57(2):7I-84.

182. Ryan CJ, Small Ej: Progress in detection and treatment of prostate cancer. Curr Opin Oncol 2005, I 7(3):257-60.

183. Canto El, Shariat SF, Slawin KM: Biochemical staging of prostate cancer. Urol Clin North Am 2003, 30(2):263-77. 